\title{
Asset Quality as a Predictor of Rural Bank Bankruptcy in Indonesia
}

Hesti Budiwati, Ainun Jariah

Department of Management, STIE Widya Gama Lumajang

Email: hestibudiwati1404@gmail.com

A R T ICLE INFO

Date of entry:

26 April 2020

Revision Date:

12 May 2020

Date Received:

15 May 2020

\section{A B S T R A C T}

The study aims to form a bankruptcy prediction model of rural bank in Indonesia at a time variation of 1 quarter (MP1), 2 quarters (MP2), 4 quarters (MP4), and 8 quarters (MP8) before bankruptcy. The quality of productive assets as a predictor variable consist of CEA, CEAEA, and NPL. The condition of rural bank bankrupt and non bankrupt as a dependent variable. The analytical method used is logistic regression followed by testing the model accuration. The population of this study is rural bank in Indonesia. The sample used was 241 rural banks that consist of 41 bankrupt rural banks and 200 non bankrupt rural banks. The data used are the quarterly financial statements of 2006 to 2019 . The study result showed that of the four prediction models that successfully built, the 1 quarter (MP1) is the most feasible and accurate used as bankruptcy prediction model of rural banks in Indonesia that formed by CEAEA and NPL ratio. The MP1 has a classification accuracy of $93,8 \%$ at the level of modelling with cut off point of 0,29 and it has a classification accuracy of $83,93 \%$ at the level of validation with cut off point of 0,12 . Based on those advantage, the MP1 was chosen as a model that able to predict the bankruptcy of rural bank in Indonesia.

Keywords: The Quality of Productive Assets, Bankruptcy, Rural Bank

Cite this as: Budiwati, H., Jariah, A. (2020). Asset Quality as a Predictor of Rural Bank Bankruptcy in Indonesia. Jurnal Ilmu Manajemen Advantage. 4(1), 45-55. https://doi.org/ 10.30741/adv.v4i1.612

\section{INTRODUCTION}

The challenges of the banking industry in Indonesia are not getting lighter due to the sharp level of competition with fellow bank financial institutions and non-bank financial institutions, which can pose a threat to a bank if it is unable to increase its competitiveness and may even lead to bankruptcy. Banks are a business that prioritizes public trust, therefore it is very important for banks to always maintain public trust. The unique type of bank is no exception, namely the Rural Bank. The Rural Bank has a unique advantage over Commercial Banks, namely simple service procedures, fast processing and flexible credit regulations. In addition, Bank Perkreditan Rakyat also excels in services to customers who prioritize a personal approach and pick up the ball. According to Indonesian banking statistics for 2018, Rural Banks in Indonesia control 93.17\% of 
all types of banks in Indonesia. Meanwhile, according to data from the Deposit Insurance Corporation, from 2006 to 27 January 2020, as many as 100 banks have been liquidated, 90 conventional Rural Banks, 9 Islamic Rural Banks and 1 Commercial Bank. This condition raises the question of what happened to the 90 conventional Rural Banks which were liquidated so that they had to go bankrupt? This is certainly interesting to research so that it can be used as a lesson or experience for other banks in managing a bank business with prudential banking principles.

To anticipate the emergence of financial difficulties at this People's Credit Bank and to anticipate the impact of the COVID-19 pandemic, a tool is needed that can be used to detect early trends in bankruptcy at Rural Banks. The main problems faced by Rural Banks in this pandemic condition include a decrease in the ability of debtors which will also result in a decrease in the quality of Rural Bank assets, so this study tries to form a system that will be used as a tool to detect the occurrence of bankruptcy earlier which is formed from the ratio ratio in asset quality. With the existence of this bankruptcy early detection tool, it will be very helpful to help the Rural Bank to take anticipatory steps, especially in the challenges of this pandemic.

This study will form a prediction model for bankruptcy of rural banks in 4 (four) time variations, namely 1, 2, 4 and 8 quarters prior to bankruptcy. The selection of time periods $1,2,4$ and 8 quarters prior to bankruptcy in this rural bank bankruptcy prediction modeling, with certain considerations. First, the uniqueness of the business character of the banking industry, where banking activities are a business that prioritizes trust, which if losing trust will lead to bankruptcy. Therefore, tools are needed to carry out early detection and provide warnings about the condition of Rural Banks ahead of bankruptcy. Second, the publication of financial reports for Rural Banks in Indonesia uses a quarterly period. Thus, the formation of prediction models based on time variations 1, 2, 4 and 8 quarters prior to bankruptcy is reasonable. With this time variation choice, it is hoped that a model will be obtained to detect the bankruptcy of Rural Banks in Indonesia. Rural Banks in Indonesia as early as possible.

The pioneers of the study of bankruptcy prediction were Beaver (1966) and Altman (1968). Beaver (1966) and Altman (1968) used company financial statement data in the form of financial ratios as discriminator and predictor variables for bankruptcy. Beaver (1966), in his study used a single variable (univariate model) with a period of 10 years, namely 1954-1964. Altman (1968) became a pioneer in the study of bankruptcy prediction using multivariate model analysis. Altman (1968) used multiple discriminant analysis techniques to predict bankruptcy. Altman's model is popularly called the Z score. Zaoghdoudi (2013), conducted a study on prediction of commercial bank failure in Tunisia using eighteen CAMEL ratios with the Binary Logistic Regression method. Pradhan (2014), examined failure estimates in the Indian banking sector using four financial ratios using the Multiple Discriminant Analysis (MDA) method, Titshabona (2014), also conducted a study on prediction of failure in banking and financial services in Zimbabwe using five financial ratios using the Z Score method - Altman and Hilman (2014), in their research, the National Private Commercial Bank bankruptcy model in Indonesia uses twenty-nine financial ratios with the Linear Discriminant Model and Logistic Regression Model.

Continuous research on bank bankruptcy is currently still ongoing, so the problems will be answered are: a) Based on the ratio in asset quality, what is the accurate prediction model for Rural Banks Bankruptcy in Indonesia? b) Which bankruptcy prediction model based on time variations is the most feasible and accurate to be used to predict bankruptcy at Rural Banks in Indonesia? Based on the background of the problem and the formulation of the proposed problem, the objectives of this study are: a. Establish an accurate prediction model for Rural Banks in Indonesia based on the ratio of asset quality. b. Determine the most feasible and accurate prediction model used to predict bankruptcy at Rural Banks in Indonesia. 


\section{METHODS}

This research is a type of explanatory research in which the research variables consist of the ratio in asset quality ratios consisting of CEA, CEAEA and NPL which are used to predict the trend of bankruptcy of Rural Banks in Indonesia. This study is designed to explain the ability of the independent variables from the ratio of the ratio in asset quality consisting of CEA, CEAEA and NPL in forming a prediction model for bankruptcy of rural banks in Indonesia. The predictor variable from the ratio of the ratio in asset quality consists of CEA, CEAEA and NPL with the consideration that the current pandemic condition has decreased the ability of debtors to fulfill their obligations to Rural Banks which can have an impact on asset quality managed by Rural Banks.

The dependent variable Y, namely bankruptcy status and time variation (XT), is dichotomous. Time variations are distinguished by using financial reports 1, 2, 4 and 8 of the quarter before bankruptcy. The selection of time periods 1, 2, 4 and 8 quarters prior to bankruptcy in the prediction modeling for Bank Perkreditan Rakyat bankruptcy, with the consideration that the publication of financial reports for Rural Banks in Indonesia uses the quarterly period.

The target population in this study is the financial statements of all Rural Banks in Indonesia in the category of bankrupt and non-bankrupt banks spanning the period 2006 to 2019. Considerations for determining the population in that period are: a. 2006 to 2019 was a period in which the number of rural banks in Indonesia that were declared bankrupt increased. b. Even though rural banks are small in scale, most of their customers are small and micro community groups so that their existence also needs attention.

The Rural Banks that were sampled were divided into two categories, namely bankrupt rural banks and non-bankrupt rural banks. The sampling technique used was purposive sampling. A bankrupt Rural Bank is a Rural Bank that meets the following criteria: a. Conventional Rural Banks in Indonesia. b. Bank Perkreditan Rakyat in Indonesia which was declared bankrupt and in the process of bankruptcy by the financial authorities from 2006 to 2019. c. Actively publishing financial reports before being declared bankrupt in the Financial Services Authority directory.

d. Have the required financial reports consisting of balance reports and other information reports. Banks that are included in the group of Rural Banks that are not bankrupt are determined by the following criteria: a. Conventional Rural Banks in Indonesia. b. Rural Banks in Indonesia that are still operating and actively publish their financial reports in the directory of the Financial Services Authority. c. Rural Banks in Indonesia that have not been declared bankrupt by the competent financial authorities. d. Have complete financial reports consisting of balance reports and other information reports. Based on the specified sample criteria, 41 bankrupt rural banks were sampled and 200 rural rural banks were not bankrupt samples.

The research sample data was divided into 2 (two) groups, namely design subsample and validation subsample. Referring to Sumarno (1994: 23), what is meant by design sample is the sample used to build a prediction model. The validation sample is the sample used in the validation test of the prediction model generated from the design sample. The data used for the sample design is the quarterly financial report data for Rural Banks in Indonesia for the period 2006 to 2017, while the validation sample is the quarterly financial report data for Rural Banks in Indonesia for the period 2018 and 2019. According to Sumarno (1994: 23), a model should be evaluated by testing the accuracy of its predictions based on design and validation samples. As long as the data used for validation accuracy is different from the data used to form the classification function (or prediction), the error rate obtained is unbiased (Rencher, 1995: 337). The sample size ratio in most empirical studies shows that the n-design sample is greater than the n-validation sample

The independent variable (Xi) as a predictor variable in this study is the ratio of the asset quality ratio which is used to measure the quality of its productive assets rural banks. Meanwhile, the 
dependent variable (Y) is the bankruptcy status of rural banks. The considerations for using asset quality ratios as a predictor of bankruptcy for rural banks are: (1) the impact of the current pandemic conditions on the decline in the ability of debtors to meet their obligations will have an impact on the quality of productive assets of Rural Banks, (2) in previous empirical studies, earning asset quality ratios are also indicators that can be used as predictors of bank bankruptcy. The dependent variable Y, namely bankruptcy status is dichotomous, therefore bankruptcy status is a dummy variable and has a nominal scale. The independent variable has a ratio scale consisting of: X1: Classified Earning Assets (CEA), X2: Classified Earning Assets / Earning Assets (CEAEA), X3: Non Performing Loan (NPL), The dependent variable in this study is the bankruptcy status of Rural Banks in Indonesia which have been declared bankrupt by the Safe Deposit Insurance Corporation and the healthy Rural Banks. The use of time variations in the form of rural bank financial reports for 1 quarter, 2 quarters, 4 quarters and 8 quarters prior to bankruptcy in order to determine the appropriate time variations to predict bankruptcy.

The following is the operational definition of the variables used as predictors in shaping the bankruptcy model: CEA (Classified Earning Assets) (X1). It is the collectability of all productive assets owned by Rural Banks to generate income in accordance with their function, which comes from the capital of Rural Banks. Collectability is the classification as under special supervision, substandard, doubtful and stuck. The CEA ratio is obtained from the comparison of earning assets classified with rural bank capital, which consists of core capital and supplementary capital. The calculation of classified earning assets is carried out by giving the percentage weights as follows: 1) $25 \%$ of the earning assets classified under Special Supervision, 2) 50\% of earning assets classified as Substandard, 3) 75\% of earning assets classified as Doubtful, 4) 100\% of earning assets classified as Loss

CEAEA (Classified Earning Assets Compared to Earning Assets) (X2). Represents the collectability of all earning assets owned by Rural Banks to earn income according to their function, originating from the total earning assets. The APYDAP ratio is obtained from the comparison of earning assets classified with earning assets.

NPL (Non Performing Loan) $\left(\mathrm{X}_{4}\right)$. This is the amount of loans that have been channeled and are categorized as non-performing, which consists of loans in the substandard, doubtful and loss categories. The NPL ratio is obtained from the ratio between the amount of loans and the total earning assets of a Rural Bank. Non performing earning assets are earning assets with substandard, doubtful and loss quality, which are calculated on a gross basis (not reduced by PPAP).

The analysis method used is logistic regression analysis where each prediction model in this study goes through the following stages: a. Build a bankruptcy prediction model. The prediction model is built based on the logistic regression model formulated by the following equation:

$$
\begin{aligned}
& P_{i}=E(Y=1) X_{i, t-k}=\frac{1}{\left.1+e^{-\beta_{0}}+\sum_{k j=1}^{j} \beta_{1} x_{i j . t-k}\right)} \\
& \left.P_{i}=\frac{1}{1+e^{-Z t}} \quad Z_{i t}=-\beta_{0}+\sum_{\text {and }}^{j} \beta_{1} X_{i j, t-k}\right)
\end{aligned}
$$

Where, Pi : the opportunity for the ith BPR to go bankrupt, Xij: predictor variable $\mathrm{j}$ for BPR i, Zi: linear function of the predictor variable; - oo $\leq \mathrm{Zi} \leq+\mathrm{oo}$, $\mathrm{t}$ : when the BPR goes bankrupt, $\mathrm{k}$ : the period (months) before the BPR goes bankrupt, e: natural logarithm; e $=2.71828$, b: regression coefficient. 
Then the equation is adjusted by entering the variable XT (time variation). The time variation group consists of 4 groups of the period before bankruptcy, namely 1 quarter, 2 quarter, 4 quarter and 8 quarter before bankruptcy, so the number of dummy variables is $\mathrm{D}=\mathrm{k}-1=4-1=3$. Time variation dummy variable $\left(\mathrm{X}_{\mathrm{T}}\right)$ put in the equation to be:

$$
\left.P_{i}=\frac{1}{1+e^{-Z t}} ; \text { dan } \quad Z_{t}=\beta_{0}+\beta_{i} D_{i}+\sum_{p=1}^{m} \beta_{p} \beta_{p}\right)+1+f_{p}
$$

Prediction Model Verification. Furthermore, to find out how good the logistic regression results are, as a verification step, several testing steps are carried out on equation (3) as follows (Stock \& Watson, 2007, in Widarjono, 2015: 112): Goodness of Fit $\mathrm{R}^{2}$. Goodness of fit is used to determine the goodness of the prediction model using the Hosmer and Lemeshow measure which measures the difference between the observed value and the predicted value of the dependent variable. The smaller the difference between the two, the better / feasible the model obtained (Hair et.al, 1998: 318). The criteria used: If the sig value $>\alpha$, then the model is said to be fit. If the sig value $<\alpha$, then the model is said to be unfit. In addition, to find out the goodness of the prediction model, a Pseudo R2 measure that is often used in logistic regression models is used, namely Pseudo R2 Cox and Snell and Pseudo R2 Nagelkerke. Cox and Snell R2 has a weakness, namely the value never approaches 1, so the model modification is done using Nagelkerke R2. The criterion used is that the greater the $\mathrm{R} 2$ value, the better the prediction model produced.

Overall Model Fit is used to determine whether all the independent variables in the prediction model simultaneously affect the dependent variable. The simultaneous significance test used the Chi Square value. Hypothesis for assessing simultaneous significance tests: Ho: there is no significant effect simultaneously, H1: there is a significant effect simultaneously, The criteria used: If Chi Square (R2) counts <Chi Square (R2) table, then Ho is accepted. If Chi Square (R2) count $>$ Chi Square (R2) table, then Ho is rejected.

The Individual significance test is used to determine whether all the independent variables in the prediction model individually affect the dependent variable. The criteria used: If the sig value $>\alpha$, then Ho is accepted, it means that there is no individual influence. If the sig value $<\alpha$, then Ho is rejected, it means that there is an individual influence. Odds Ratio, which is the value of Exp (B), is used to determine how much the predictor variable tends to affect the bankruptcy of rural banks.

Furthermore, to prove that the prediction model for the bankruptcy of Rural Banks is accurate, a Power of Regression to Predict analysis is performed. The power of regression to predict test is the predictive power of the prediction model for the probability of rural banks experiencing bankruptcy or not. The prediction model will produce a score between 0 (zero) and 1 (one) which is interpreted as a probability number. A cut-off-point is a value to determine whether a Rural Bank is estimated to be a bankrupt or non-bankrupt Rural Bank. The cut-off-point value is indicated by the correct estimates, the higher the correct estimates value, the stronger the predictive power of the prediction model formed and vice versa.

This research has the advantage that in addition to producing a bankruptcy prediction model, this study also assesses the performance of the bankruptcy prediction model formed from the estimated data. Several previous studies on bank bankruptcy did not all validate the prediction model. In fact, the performance appraisal of a predictive model is a prerequisite if the research objective is to predict an event, namely by making empirical comparisons (Beaver, Kennelly, \& Voss, 1968. According to Sumarno (1994: 50), in general, to test models in failure prediction research using classification accuracy methods both on design and validation samples. 


\section{RESULTS AND DISCUSSION}

Observations were made at bankrupt and non-bankrupt People's Credit Banks in Indonesia for the period 2006 to 2019 which were the population in this study. Based on the specified sample criteria, a sample of Rural Banks is obtained which is presented in table 1 below

Table 1. Proportion of Research Samples

\begin{tabular}{lllllll}
\hline \multicolumn{1}{c}{ Information } & \multicolumn{2}{c}{ Design Sampel } & \multicolumn{2}{c}{ Validation Sample } & \multicolumn{2}{c}{ Total } \\
\hline & $\mathbf{N}$ & Prop (\%) & $\mathbf{N}$ & \multicolumn{1}{c}{ Prop (\%) } & N & Prop (\%) \\
\hline Bankruptcy BPR & 29 & 22,48 & 12 & 10,71 & 41 & 17,01 \\
\hline BPR is not bankrupt & 100 & 77,52 & 100 & 89,29 & 200 & 82,99 \\
\hline Jumlah & 129 & 100 & 112 & 100 & 241 & 100 \\
\hline
\end{tabular}

Source : Direktori Otoritas Jasa Keuangan, 2020.

The prediction model for bankruptcy of rural banks in Indonesia is built based on predictors in the form of a ratio of asset quality ratios consisting of CEA, CEAEA and NPL for 4 (four) time variations, namely 1 quarter, 2 quarters, 4 quarters and 8 quarters prior to bankruptcy, hereinafter abbreviated as with MP1, MP2, MP4 and MP8. By using logistic regression analysis, the prediction model for bankruptcy of Rural Banks in Indonesia is obtained at 4 (four) time variations as follows:

The MP1 bankruptcy prediction model is formed from data 1 quarter before bankruptcy, the results of the computational logistic regression are as follows

Table 2. Logistic Regression Computation Results for Bankruptcy Model MP1

\begin{tabular}{llllll}
\hline $\begin{array}{c}\text { Variabel } \\
\text { (in step 2) }\end{array}$ & \multicolumn{1}{c}{$\boldsymbol{\beta}$} & SE & Wald & Signifikansi & Exp (B) \\
\hline CEAEA & 0,074 & 0,021 & 12,572 & 0,000 & 1,077 \\
\hline NPL & 0,272 & 0,079 & 11,740 & 0,001 & 1,313 \\
\hline Constant & $-6,355$ & 1,377 & 21,306 & 0,000 & 0,002 \\
\hline Chi Square & & & & & \\
\hline
\end{tabular}

Chi Square $=107,596($ sig $=0,000)$

Source: Data processed from Direktori Otoritas jasa Keuangan, 2020.

Then the equation of the MP1 prediction model that is formed is MP1 =

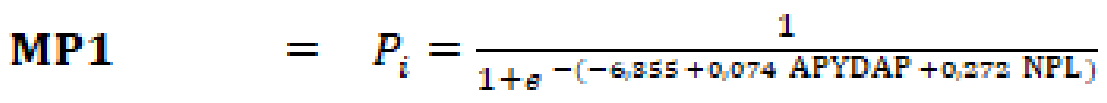

Table 2 shows that CEAEA has a significant value of 0.000 with an Exp (B) value of 1.077, which means that CEAEA tends to affect the bankruptcy of Rural Banks by 1.077. Meanwhile, NPL has a significant value of 0.001 with an Exp (B) value of 1.313, which means that the NPL tends to affect the bankruptcy of Rural Banks by 1.313 .

The results of the goodness of fit test as measured by the Hosmer and Lemeshow test show that MP1 has a probability value of $\operatorname{sig}=1,000$. Because the value of $\operatorname{sig}(1,000)>\alpha(0.05)$, Ho is accepted and $\mathrm{H} 1$ is rejected, the conclusion is that the classification of rural banks is bankrupt and not bankrupt, which is predicted by the MP1 equation does not differ significantly at $\alpha=5 \%$ with the classification of bankrupt rural banks. and no bankruptcy is observed. Thus the MP1 equation is stated as a regression model that is fit or fit for use because the resulting model can predict the value of the observations. Measured by the value of R2 Cox and Snell and R2 Nagelkerke MP1 has a value of 0.863 which means the variability of the dependent variable which can be explained by the variability of the independent variable is $86.3 \%$. Furthermore, the Overall Model Fit simultaneous significance test is performed to determine whether all the independent variables in the prediction model simultaneously affect the dependent variable. Obtained chi square value of 
107.596 with sig 0.000 , the conclusion is that all independent variables in the prediction model simultaneously affect the dependent variable. Whereas for the individual significance test, the CEAEA significance value (sig.0,000) and the NPL significance value (sig.0,001) were obtained, both of which were below sig.0.05 ( $\mathrm{sig}<0.05$ ), it can be concluded that CEAEA and NPL individually had a significant effect. the dependent variable. With a cut-off of 0.29 , in which the proportion between the number of bankrupt rural banks and non-bankrupt rural banks in the design sample data, namely 29 bankrupt rural banks compared to 100 rural banks not bankrupt, overall MP1 proved capable of classifying 129 rural banks. which was observed with an accuracy rate of $93.8 \%$. On the basis of this percentage accuracy, the MP1 is considered to have good performance.

The MP2 bankruptcy prediction model is formed from 2 quarters of data before bankruptcy, the results of the logistic regression computation are as follows:

Table 3. Logistic Regression Computation Results for Bankruptcy Model MP1

\begin{tabular}{lccccc}
\hline $\begin{array}{c}\text { Variabel } \\
\text { (in step 2) }\end{array}$ & \multicolumn{1}{c}{$\boldsymbol{\beta}$} & SE & Wald & Signifikansi & Exp (B) \\
\hline CEAEA & 0,055 & 0,016 & 11,607 & 0,001 & 1,057 \\
\hline NPL & 0,160 & 0,047 & 11,487 & 0,001 & 1,173 \\
\hline Constant & $-3,859$ & 0,609 & 40,161 & 0,000 & 0,021 \\
\hline
\end{tabular}

Chi Square $=75,990($ sig $=0,000)$

Source: Data processed from Direktori Otoritas jasa Keuangan, 2020.

Then the MP2 prediction model equation that is formed is

MP2

$$
=P_{i}=\frac{1}{1+e-(-8,859+0,055 \text { APYDAP }+0,160 \mathrm{NPL})}
$$

Table 3 shows that CEAEA has a significant value of 0.001 with an Exp (B) value of 1.057, which means that CEAEA tends to affect the bankruptcy of Rural Banks by 1.057. Meanwhile, NPL has a significant value of 0.001 with an $\operatorname{Exp}(B)$ value of 1.173 , which means that the NPL tends to affect the bankruptcy of Rural Banks by 1.173 .

The results of the goodness of fit test as measured by the Hosmer and Lemeshow test show that MP2 has a probability value of sig $=0.360$. Because the value of $\operatorname{sig}(0.360)>\alpha(0.05)$, the conclusion is that the classification of bankrupt and non-bankrupt Rural Banks predicted by the MP2 equation does not differ significantly at $\alpha=5 \%$ with the observed bankrupt and non-bankrupt Rural Banks classification. Thus the MP2 equation is stated as a regression model that is fit or fit for use because the resulting model can predict the value of the observations. Measured by the value of R2 Cox and Snell and R2 Nagelkerke MP2 has a value of 0.679 which means the variability of the dependent variable which can be explained by the variability of the independent variable is $67.9 \%$. Furthermore, the Overall Model Fit simultaneous significance test was carried out and obtained a chi square value of 75.990 with sig 0.000 , so the conclusion is that all independent variables in the prediction model simultaneously affect the dependent variable. Whereas for the individual significance test, the CEAEA significance value (sig.0,001) and the NPL significance value (sig.0,001) were obtained, both of which were below sig.0.05 (sig <0.05), it can be concluded that CEAEA and NPL individually had a significant effect. the dependent variable. With a cut-off of 0.29 , overall MP2 proved capable of classifying 129 observed rural banks with an accuracy rate of $90.7 \%$. On the basis of this accuracy percentage, MP2 is considered to have good performance.

The MP4 bankruptcy prediction model is formed from 4 quarters of data prior to bankruptcy, the results of the logistic regression computation are as follows: 
Table 4. Logistic Regression Computation Results for the MP4 Bankruptcy Model

\begin{tabular}{llcccc}
\hline $\begin{array}{c}\text { Variabel } \\
\text { (in step 2) }\end{array}$ & $\boldsymbol{\beta}$ & SE & Wald & Signifikansi & Exp (B) \\
\hline CEA & 0,009 & 0,003 & 10,852 & 0,001 & 1,009 \\
\hline CEAEA & 0,289 & 0,060 & 23,057 & 0,000 & 1,335 \\
\hline Constant & $-5,237$ & 0,901 & 33,790 & 0,000 & 0,005 \\
\hline
\end{tabular}

Chi Square $=78,665($ sig $=0,000)$

Source: Data processed from Direktori Otoritas Jasa Keuangan, 2020.

Then the MP4 prediction model equation that is formed is

MP4 $\quad=\quad P_{i}=\frac{1}{1+e^{-(-5,287+0,009 \text { APYD }+0,289 \text { APYDAP })}}$

Table 4 shows that CEA has a significant value of 0.001 with an Exp (B) value of 1.009, which means that CEA tends to affect the bankruptcy of Rural Banks by 1.009. While CEAEA has a significant value of 0.000 with an $\operatorname{Exp}(\mathrm{B})$ value of 1.335 , which means that CEAEA tends to affect the bankruptcy of Rural Banks by 1.335 .

The results of the goodness of fit test as measured by the Hosmer and Lemeshow test show that MP4 has a probability value of $s i g=0.846$. Because the value of sig $(0.846)>\alpha(0.05)$, the conclusion is that the classification of bankrupt and non-bankrupt Rural Banks predicted by the MP4 equation does not differ significantly at $\alpha=5 \%$ with the observed bankrupt and non-bankrupt Rural Banks classification. Thus the MP4 equation is stated as a regression model that is fit or fit for use because the resulting model can predict the value of the observations. Measured by the value of R2 Cox and Snell and R2 Nagelkerke MP4 has a value of 0.696 which means the variability of the dependent variable which can be explained by the variability of the independent variable is $69.6 \%$. Furthermore, the Overall Model Fit simultaneous significance test was carried out and obtained a chi square value of 78.665 with sig 0.000 , so the conclusion is that all independent variables in the prediction model simultaneously affect the dependent variable. Whereas for the individual significance test, the CEA significance value (sig.0,001) and the CEAEA significance value (sig.0,000) were obtained, both of which were below sig.0.05 (sig $<0.05$ ), it can be concluded that CEA and CEAEA individually had a significant effect. the dependent variable. With a cut-off of 0.29 , overall the MP4 was proven capable of classifying 129 observed rural banks with an accuracy rate of $88.4 \%$. On the basis of this accuracy percentage, MP4 is considered to have good performance

The MP8 bankruptcy prediction model is formed from data from 8 quarters prior to bankruptcy, the results of the logistic regression computation are as follows:

Table 5. Results of the MP8 Bankruptcy Model Logistic Regression Computation

\begin{tabular}{llllll}
\hline $\begin{array}{c}\text { Variabel } \\
\text { (in step 2) }\end{array}$ & \multicolumn{1}{c}{$\beta$} & SE & Wald & Signifikansi & Exp (B) \\
\hline CEA & 0,016 & 0,004 & 15,324 & 0,000 & 1,017 \\
\hline CEAEA & 0,041 & 0,017 & 5,825 & 0,016 & 1,042 \\
\hline NPL & 0,191 & 0,059 & 10,653 & 0,001 & 1,210 \\
\hline Constant & $-5,950$ & 1,032 & 33,790 & 0,000 & 0,003 \\
\hline
\end{tabular}

Chi Square $=75,294($ sig $=0,000)$

Source: Data processed from Direktori Otoritas Jasa Keuangan, 2020.

Then the MP8 prediction model equation that is formed is

MP8 1 
Table 5 shows that CEA has a significant value of 0.000 with an Exp (B) value of 1.017, which means that CEA tends to affect the bankruptcy of Rural Banks by 1.017. CEAEA has a significant value of 0.016 with an Exp (B) value of 1.042 which means that CEAEA tends to affect the bankruptcy of Rural Banks by 1.042 and NPL has a significant 0.001 with an Exp (B) value of 1.210, which means that NPL tends to affect the bankruptcy of Rural Banks by 1.201.

The results of the goodness of fit test as measured by the Hosmer and Lemeshow test show that MP8 has a probability value of $\operatorname{sig}=0.064$. Because the sig value $(0.064)>\alpha(0.05)$, the conclusion is that the classification of bankrupt and non-bankrupt Rural Banks predicted by the MP8 equation does not differ significantly at $\alpha=5 \%$ with the observed bankrupt and non-bankrupt Rural Banks classifications. Thus the MP8 equation is stated as a regression model that is fit or fit for use because the resulting model can predict the value of the observations. Measured by the value of R2 Cox and Snell and R2 Nagelkerke MP8 has a value of 0.674 which means the variability of the dependent variable which can be explained by the variability of the independent variable is $67.4 \%$. Furthermore, the Overall Model Fit simultaneous significance test was carried out and obtained a chi square value of 75.294 with a sig of 0.000 , so the conclusion is that all independent variables in the prediction model simultaneously affect the dependent variable. Whereas for the individual significance test, the CEA significance value was obtained (sig.0,000), the CEAEA significance value (sig.0.016) and the NPL significance value (sig.0,001), all of which were below sig. 0.05 ( $\mathrm{sig}<0.05$ ). It is concluded that the CEA, CEAEA and NPL individually have a significant effect on the dependent variable. With a cut-off of 0.29 , overall MP8 proved capable of classifying 129 observed Rural Banks with an accuracy rate of $89.9 \%$. On the basis of this percentage accuracy, the MP8 is considered to have good performance

This research has the advantage that in addition to producing a bankruptcy prediction model, this study also assesses the performance of the bankruptcy prediction model formed from the estimated data. As Sumarno (1994: 23) says, a model should be evaluated by testing the accuracy of its predictions based on design and validation samples. As long as the data used for validation accuracy is different from the data used to form the classification function (or prediction), the error rate obtained is unbiased (Rencher, 1995: 337).

This stage is carried out by measuring the accuracy of the equation model in each prediction model, namely the regression model equation MP1, MP2, MP4 and MP8, using validation data in 2018 and 2019 as many as 112 Rural Banks consisting of 12 bankrupt Rural Banks and 100 Rural Banks is not bankrupt in either model. . The use of classification accuracy tables is still used to measure the accuracy of the equation model in question. . Obtained a cut-off value of 0.12 , which is the proportion between the number of bankrupt rural banks and non-bankrupt rural banks in the validation sample data, namely 12 bankrupt rural banks compared to 100 bankrupt rural banks. Therefore, if a Rural Bank has a probability above 0.12 (probability> 0.12), the Rural Bank is predicted to be classified as bankrupt. Conversely, if the Rural Bank has a probability below 0.12 (prob <0.12), the Rural Bank is predicted to be classified as a Rural Bank not bankrupt. The performance of the model formed is measured by the accuracy of the classification results

The comparison of the results of the prediction model for bankruptcy of rural banks in Indonesia based on the design sample data and the validation sample for each time variation of the model, namely MP1, MP2, MP4 and MP8 is presented in table 6 as follows: 
Table 6. Prediction Model for Rural Bank Bankruptcy in Indonesia

\begin{tabular}{lllll}
\hline \multicolumn{1}{c}{ Information } & \multicolumn{1}{c}{ MP 1 } & MP 2 & MP 4 & \multicolumn{1}{c}{ MP 8 } \\
\hline Modeling & & & & \\
Design Sample: & & & & \\
BPR bankrupt & 29 & 29 & 29 & 29 \\
BPR is not bankrupt & 100 & 100 & 100 & 100 \\
Cut-off Point & 0,29 & 0,29 & 0,29 & 0,29 \\
Correct Estimates (\%) & 93,8 & 90,7 & 88,4 & 89,9 \\
\hline Validity test & & & & \\
Validation Sample : & 12 & 12 & 12 & 12 \\
BPR bankrupt & 12 & 100 & 100 & 100 \\
BPR is not bankrupt & 100 & 0,12 & 0,12 & 0,12 \\
Cut-off Point & 0,12 & 66,96 & 63,39 & 61,61 \\
Correct Estimates (\%) & 83,93 & J &
\end{tabular}

Source: Data processed from Direktori Otoritas Jasa Keuangan, 2020.

After testing the accuracy of the prediction model in each model using validation sample data, it is found that MP1 has the ability to classify with the highest level of accuracy, namely $83.93 \%$. Therefore, the MP1 formed by CEAEA and NPL was chosen as an accurate and suitable model for predicting bankruptcy for rural banks.

\section{CONCLUSION}

The prediction model for Bank Perkreditan Rakyat in Indonesia bankruptcy is formed from a ratio of asset quality ratios consisting of the ratio of CEA, CEAEA and NPL with the consideration of a decrease in debtor capacity due to the impact of the current pandemic in Indonesia. The prediction model for bankruptcy for rural banks in Indonesia using the Asset Quality ratio is compiled based on 4 (four) time variations, namely 1 quarter, 2 quarters, 4 quarters and 8 quarters before bankruptcy, hereinafter abbreviated as MP1, MP2, MP4 and MP8. The 1-quarter prediction model or MP1 was chosen as the most feasible and accurate prediction model to use which was formed from the CEAEA and NPL predictors because it had the highest level of accuracy both in modeling and when tested with validation samples. The prediction model for Rural Banks in Indonesia bankruptcy can be used as a solution for early detection by the management of Rural Banks, to find out as early as possible whether Rural Banks has a sign of bankruptcy or not. MP1 formed by the ratio of CEAEA and NPL will greatly assist the management of Rural Banks to determine strategies in facing competition between bank and non-bank financial institutions, namely by prioritizing managing bank fund portfolios and credit portfolios by applying prudential banking principles. As well as being able to start taking more serious credit handling actions since the credit is in arrears 1 month before it's too late to handle it.

Regulators can utilize or use this rural bank prediction model as a consideration in carrying out their supervisory and coaching functions for rural banks operating in Indonesia so that to be more optimal in maintaining their credit portfolios from an early age, namely since the credit is disbursed and even so that they can take action preventive by providing healthy credit with the principle of high prudence even though it is required to remain competitive. The Shareholders of Rural Banks, have an interest in the survival of their Rural Banks. Therefore the research results are expected to be used as a control function through the board of commissioners on the performance of management in managing rural banks properly and healthily. For further research that is interested in conducting research with the same theme, it is recommended that they be able to conduct research on Sharia Rural Banks because with different principles it is possible to produce different prediction models for Rural Banks in Indonesia. It is also necessary to consider using Risk Management as stipulated in POJK number 13 / POJK.03 / 2015 concerning the 
Application of Risk Management for Rural Banks, which consists of credit risk, operational risk, compliance risk, liquidity risk, reputation risk and strategic risk

\section{REFERENCES}

Altman, E. I. (1968). Financial Ratios, Discriminant Analysis and The Prediction of Corporate Bankruptcy. The Journal of Finance, 23(4), 589-609.

Indonesia, G. B. (2004). Peraturan Bank Indonesia nomor: 6/10/PBI/2004 tentang Sistem Penilaian Tingkat Kesehatan Bank Umum. Peraturan Bank Indonesia.

Beaver, W. H. (1966). Financial Ratios as Predictors of Failure. Journal of Accounting Research, 71-111.

Beaver, W. H., Kennelly, J. W., \& Voss, W. M. (1968). Predictive Ability as a Criterion for The Evaluation of Accounting Data. The Accounting Review, 43(4), 675-683.

Fraser, DR \& LM Fraser. (1990). Evaluating Commercial Bank Performance : A Guide to Financial Analysis. Banker's Publishing Company. Rolling Meadows. Illionis.

Hair, J. F., Anderson, R. E., Tatham, R. L., \& Black, W. C. (1998). Multivariate Data Analysis. Englewood Cliff. New Jersey, USA, 5(3), 207-2019.

Hilman, I. (2014). The Bank Bankruptcy Prediction Models Based On Financial Risk (An Empirical Study on Indonesian Banking Crises). International Journal of Business, Economics and Law, 4(2), 1-16.

Otoritas Jasa Keuangan. (2015). Peraturan Otoritas Jasa Keuangan Nomor 13/POJK.03/2015 tentang Penerapan Manajemen Risiko Bank Perkreditan Rakyat. Jakarta.

Otoritas Jasa Keuangan. (2016). Statistik Perbankan Indonesia. Departemen Perizinan dan Informasi Perbankan Financial Services Authority, Republic of Indonesia Banking Licensing and Information Department. Jakarta.

Komisioner D, Jasa O. Manajemen Risiko Bank Perkreditan Rakyat.Otoritas Jasa Keuangan Republik Indonesia. 2015.

Rencher, A. C. (1995). Methods of Multivariate Analysis. John wiley\&son. Inc. Publication, Canada, 380-407.

Scott, W. R. (2015). Financial Accounting Theory Seventh Edition. United States: Canada Cataloguing.

Titshabona, N. (2014). Predicting Corporate Failure: Insights From The Financial Sector in Zimbabwe. International Journal of Economics, Commerce and Management, 2(11), 1-19. https://doi.org/10.1016/0024-6301(84)90202-4

Widarjono, A. (2015). Analisis Multivariat Terapan. Yogyakarta: UPP STIM YKPN.

Zain, Sumarno. (1994). Failure Prediction: An Artificial Intelligence Approach, Accountancy Development in Indonesia. Publication No.21. Tim Koordinasi Pengembangan Akuntansi. Jakarta.

Zaghdoudi, T. (2013). Bank Failure Prediction with Logistic Regression. International Journal of Economics and Financial Issues, 3(2), 537-543. 